\title{
Proficiencies for Instruction Librarians: Is There Still a Disconnect Between Professional Education and Professional Responsibilities?
}

\section{Theresa Westbrock and Sarah Fabian}

\begin{abstract}
In 1993, based on the proficiencies for bibliographic instruction librarians (1986), Diana Shonrock and Craig Mulder investigated if and where librarians were acquiring these proficiencies. In 2007, ACRL approved a revised set of proficiencies: Proficiencies for Instruction Librarians and Coordinators. The authors recreated the 1993 study, using the revised set of proficiencies. Librarians find the new set of proficiencies to be more relevant to their jobs than the older set of proficiencies; however, they are still most likely to acquire the proficiencies primarily outside their library school education.
\end{abstract}

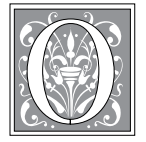

ver the past two decades, information literacy instruction has become a significant part of the duties of many academic librarians. In particular, as the electronic environment becomes more inundated with information and the skills required to conduct research at the college level become more complex, librarians play an important role in helping students gain the necessary skills to navigate, understand, and assess this vast world of information. Students often develop these skills through instruction sessions led by librarians or research instruction integrated throughout an entire course, but where are librarians learning the skills necessary to be competent and effective teachers? Are library schools preparing future librarians for their roles as classroom instructors, or are librarians primarily learning these skills on the job through trial and error?

In 1986, the Association of College and Research Libraries (ACRL) Bibliographic Instruction Section (BIS) defined a set of proficiencies for bibliographic instruction librarians ${ }^{1}$ (see table 1 ). A primary purpose of this document was to advise library schools in their curriculum and course planning. In 1993, Diana Shonrock and Craig Mulder used these proficiencies as a basis for discovering what skills library instructors found the most useful in their jobs. Their project consisted of analyzing data from two surveys involving these proficiencies. In the first survey, Shonrock and Mulder asked librarians to rank the importance of each of the proficiencies. In the second survey, they took a select set of these proficiencies and asked instruction

Theresa Westbrock is Instruction Coordinator at New Mexico State University Library; e-mail: twestbro@ nmsu.edu. Sarah Fabian is First Year Experience Librarian in the Halle Library at Eastern Michigan University; e-mail: sfabian@emich.edu. (c) Theresa Westbrock and Sarah Fabian 


\begin{tabular}{|c|}
\hline $\begin{array}{c}\text { TABLE 1 } \\
\text { Proficiencies for Instruction Librarians, } 1985\end{array}$ \\
\hline $\begin{array}{l}\text { ABILITY TO WRITE GOALS AND OBJECTIVES } \\
\text { - Understands principles and importance of setting goals and objectives } \\
\text { - Is able to write measurable behavioral goals and ongoing objectives } \\
\text { - Is able to design the curriculum for the goal }\end{array}$ \\
\hline $\begin{array}{l}\text { INSTRUCTIONAL ABILITY } \\
\text { - Understands learning theory and the psychology of learning } \\
\text { - Understands educational methods and instructional design } \\
\text { - Understands the strength and weaknesses of diverse teaching methods } \\
\text { - Understands testing and evaluation theory } \\
\text { - Is able to assess student needs using appropriate assessment tools } \\
\text { - Is able to evaluate a course by its syllabus to decide appropriate bibliographic instruction component } \\
\text { - Is able to match instructional method to a given objective } \\
\text { - Is able to match instructional method to a given academic level }\end{array}$ \\
\hline $\begin{array}{l}\text { ABILITY TO WRITE LESSON PLANS } \\
\text { - Is able to break a large unit into component parts } \\
\text { - Is able to design incremental learning tasks } \\
\text { - Is able to design tasks of various types } \\
\text { - Is able to determine a reasonable amount and level of information to be presented in a lesson plan } \\
\text { - Is able to sequence information in a lesson plan } \\
\text { - Is able to construct assignments which reinforce learning in a lesson plan }\end{array}$ \\
\hline $\begin{array}{l}\text { COMMUNICATION SKILLS } \\
\text { - Is able to organize and structure ideas logically } \\
\text { - Is able to deliver lectures, vary pace and tone, use eye contact, use appropriate gestures, etc. } \\
\text { - Is able to stimulate discussion and questions } \\
\text { - Is able to verbalize search strategy } \\
\text { - Is able to give clear, logical instructions } \\
\text { - Is able to explain abstractions by devising analogies, metaphors, etc. }\end{array}$ \\
\hline $\begin{array}{l}\text { ABILITY TO EMPLOY RESEARCH AND EVALUATION METHODOLOGIES } \\
\text { - Is able to design an evaluative instrument and to use survey techniques } \\
\text { - Is able to interpret feedback and use it to modify activity } \\
\text { - Is able to solicit and analyze student comments and attitudes } \\
\text { - Understands the structure of information within various disciplines and the categories of tools } \\
\text { necessary to use the information } \\
\text { - Understands basic statistical concepts and methods } \\
\text { - Understands validity and reliability measures for research use } \\
\text { - Inderstands SPSS or other computerized statistical packages } \\
\text { - Is able to develop a search strategy }\end{array}$ \\
\hline $\begin{array}{l}\text { MEDIA SKILLS } \\
\text { - Understands the different types of media and the pedagogical advantages and disadvantages of each } \\
\text { - Is able to assess appropriateness of media for type and size of class and size of room } \\
\text { - Is able to use media equipment slides, projectors, film, videotape, etc. } \\
\text { - Is able to design and produce appropriate instructional materials, such as written scripts, com- } \\
\text { puter programs, point-of-use aids, etc. }\end{array}$ \\
\hline $\begin{array}{l}\text { PLANNING ABILITY } \\
\text { - Understands technological developments which may affect bibliographic instruction } \\
\text { - Is able to conduct a needs assessment } \\
\text { - Is able to develop a general policy and procedural statements } \\
\text { - Is able to plan a program based on goals and objectives and anticipates the growth implications } \\
\text { - Is able to make short and long range plans } \\
\text { - Understands campus curricular needs as part of the planning process } \\
\text { - Understands campus policies as part of the planning process } \\
\text { - Is able to relate aims of the institution to bibliographic instruction and BI to other library services } \\
\text { - Is able to distinguish different levels of bibliographic instruction }\end{array}$ \\
\hline
\end{tabular}




\begin{tabular}{|c|}
\hline $\begin{array}{c}\text { TABLE } 1 \\
\text { Proficiencies for Instruction Librarians, } 1985\end{array}$ \\
\hline $\begin{array}{l}\text { ADMINISTRATIVE ABILITY } \\
\text { - Understands management principles and theory } \\
\text { - Understands authority lines and organizational structure } \\
\text { - Is able to work with administrative personnel } \\
\text { - Is able to work with committees and other library departments } \\
\text { - Is able to delegate, manage differences, deal with ambiguity and change } \\
\text { - Ability to inspire the confidence and respect of the library director and other supervisors }\end{array}$ \\
\hline $\begin{array}{l}\text { BUDGETING ABILITY } \\
\text { - Understands budgeting methods generally and specific budget procedures of one's campus } \\
\text { - Is able to analyze resources needed to implement an instructional program } \\
\text { - Is able to formulate and justify an accurate budget for a bibliographic instruction program } \\
\text { - Understanding of grantmanship and external funding sources } \\
\text { - Is able to write funding proposals }\end{array}$ \\
\hline $\begin{array}{l}\text { ABILITY TO PLAN STAFFING } \\
\text { - Is able to assess types of staff and numbers of staff needed for various instructional activities } \\
\text { - Is able to assess the strengths and weaknesses of the staff in the institution } \\
\text { - Is able to work within the library to enlist existing staff to participate in the program } \\
\text { - Understands hiring procedures and policies, including Affirmative Action } \\
\text { - Is able to write accurate job descriptions }\end{array}$ \\
\hline $\begin{array}{l}\text { ABILITY TO TRAIN AND EVALUATE } \\
\text { - Is able to draft a training program for bibliographic instruction librarians } \\
\text { - Is able to develop a performance document to be used in evaluating bibliographic instruction } \\
\text { librarians } \\
\text { - Is able to write a performance appraisal with appropriate levels of candor and tact } \\
\text { - Understands principles of public relations } \\
\text { - Understands faculty priorities and value systems } \\
\text { - Inderstands student assignments and the role of the library in completing these assignments } \\
\text { - Is able to devise public relations plan and evaluate its success or failure } \\
\text { - Is able to conduct workshops and practical team projects and supervisory guidance } \\
\text { - Is able to write training manuals and aids } \\
\text { - Is able to make positive suggestions for alternate behavior }\end{array}$ \\
\hline $\begin{array}{l}\text { ABILITY TO PROMOTE A BIBLIOGRAPHIC INSTRUCTION PROGRAM } \\
\text { - Is able to be persistent and persuasive in "selling" bibliographic instruction to administration } \\
\text { and faculty } \\
\text { - Is able to find the best paths of communication within the institution and use them to promote } \\
\text { bibliographic instruction } \\
\text { - Is able to identify discrete library skills of relevance to student assignments }\end{array}$ \\
\hline $\begin{array}{l}\text { ABILITY TO EVALUATE THE OVER A LL EFFECTIVENESS OF THE PROGRAM } \\
\text { - Is able to seek feedback regularly from the librarians offering instruction as part of the evalua- } \\
\text { tion process } \\
\text { - Understands what is reasonably expected of students at different academic levels } \\
\text { - Is able to project a reasonable outcome of the program } \\
\text { Is able to measure implementation of the program against previously established numerical } \\
\text { goals for participation } \\
\text { - Is able to assess whether the program being offered meets the needs of the students and faculty } \\
\text { - Is able to identify problem areas and suggest measures to correct these } \\
\text { searching, or other library services }\end{array}$ \\
\hline SOURCE: http://library.csus.edu/services/inst/indiv/acrl_bis_profic.htm \\
\hline
\end{tabular}


librarians how and where they acquired these skills and where they would have liked to acquire them. They discovered that librarians were largely learning these skills on the job, but would have preferred to have learned them in library school. ${ }^{2}$

In 2007, the Instruction Section of ACRL approved a new set of proficiencies for instruction librarians. Using this new list of proficiencies, the authors recreated Shonrock and Mulder's 1993 study to investigate the changes that have occurred in this realm over the past two decades. Like Shonrock and Mulder's study, this project involved analyzing data from two surveys, consisting of the same questions that Shonrock and Mulder asked in their 1993 study. Because, at the time of conducting this project, no other researchers had either recreated Shonrock and Mulder's study or appeared to be working on any sort of empirical research surrounding the new set of proficiencies, the authors chose to recreate the 1993 study as closely as possible. However, it is important to note that, while the methods of investigation are the same in both studies, the authors recreated the study using a new, updated set of proficiencies that is distinct from the set used in Shonrock and Mulder's study. The authors were primarily interested in discovering trends in librarian attitudes over time regarding where instructional proficiencies are acquired and should be acquired.

\section{Development of the Proficiencies}

In 2004, the ACRL Instruction Section Proficiencies for Instruction Librarians Task Force was charged to create a set of proficiencies for instruction librarians "focusing on broad areas of proficiency rather than a comprehensive list of skills." ${ }^{3}$ The task force identified broad categories and associated with them specific proficiencies that were appropriate to expect from instruction librarians, as well as a separate set of proficiencies that were associated with coordinators of instruction programs. The purpose of the standards was to create a set of guidelines to assist instruction librarians in improving and/or expanding their skill sets, as well as help programs clearly define responsibilities of instruction librarians. Interestingly, there is no mention of informing library school curricula with the proficiencies.

In June 2007, the Instruction Section of ACRL approved and published the revised set of proficiencies for instruction librarians: Proficiencies for Instruction Librarians and Coordinators. ${ }^{4}$

\section{Review of the Literature}

Due to the nature of this study, the authors chose to look only at literature published after Shonrock and Mulder's 1993 study. Since then, much has continued to be written about the changing nature of the work of instruction librarians, and how their positions have become increasingly important to the missions of teaching and learning on college and university campuses. Much of this literature notes that, due to this shift in responsibilities, it is now imperative that instruction librarians be prepared for their roles as teachers and that employers value teaching skills and experience in prospective employees. ${ }^{5}$

Despite Shonrock and Mulder's recommendations, much of the current literature reports librarians are still not being adequately prepared through professional coursework for their roles as teachers. In 1999, Lynn Westbrook looked at a number of different studies of library school offerings in instruction; the earliest, conducted in 1976, found that only four schools offered courses on library instruction. ${ }^{6}$ Westbrook then studied the Web sites of all library schools in the United States (except Puerto Rico) to identify courses that met three criteria: course depth (at least 3 credit hours); curricular integration (not a special topics class, must be offered at least once per year); and focus (titles had to reflect a focus on user education, information literacy, and the like). She found 26 schools that met these criteria, as well as others that offered special topics or abbreviated courses on this subject that were not included in the total. Westbrook 
concluded that, while the increase in curricular offerings was an improvement, "there are still twenty-two schools without established, separate courses on user education. All in all, the progress is meaningful but, it may be argued, incomplete" as the instructional role of librarians is even more important than it was a few decades ago when these studies began. ${ }^{7}$

In 2002, Albrecht and Baron looked at how, in light of new ACRL Information Literacy Standards, library schools were training prospective librarians to teach these skills. They looked at the Web sites of 41 LIS programs and found that 26 of these offered a class or classes in bibliographic instruction, user education, or information literacy, but many of these courses were designed for librarians planning to be school media specialists. The authors of this study also found that only four of the programs required the course as part of the core curriculum. Additionally, Albrecht and Baron sent an e-mail survey to the deans of 49 LIS programs; of the 26 respondents, only one indicated that the program had an instruction requirement. The authors did find, however, that instructional content was part of a number of other classes in these programs. ${ }^{8}$ In a study published in 2005, Heidi Julien studied the Web sites of ninety-three MLIS programs worldwide and determined that 45 offered a course in instruction (meaning that the majority of programs did not). ${ }^{9}$ Most recently, Sproles, Johnson, and Farison determined that $46(82.5 \%)$ of the 54 ALA-accredited MLIS programs in North America have a class focused on instruction. However, this number includes courses focused on school libraries, and the authors did not note how many of these courses are part of their program's core curriculum. ${ }^{10}$

While it seems that library school administrators have been reluctant to make revolutionary changes to curricula, librarians themselves have not ignored the important shift that has taken place in terms of their roles as educators on campuses. Much of the literature on the instructional role of academic librarians indicates that some institutions have been taking steps toward developing in-house professional development programs that address the need to teach librarians those pedagogical skills that they missed in graduate school. Scott Walter, in "Instructional Improvement: Building Capacity for the Professional Development of Librarians as Teachers," details the ways in which academic librarians have and can continue to learn from best practices in the "instructional improvement" movement in higher education. Walter notes that "one of the basic tenets of research and practice in instructional improvement is that an effective orientation to teaching is crucial to new faculty as they begin their professional development as teachers, but there is limited evidence of substantive and formal orientation programs focused on teaching in libraries." Walter finds that two things are critical to the ongoing development of the teaching library: further inquiry into best practices for orientation and mentoring programs focused on instruction, along with further study of the role of senior administrators as instructional leaders in the library and advocates for the importance of the library as a center of teaching and learning. ${ }^{11}$

While, as Walter notes, there is limited evidence of professional development programs on instruction in libraries, literature on this topic does exist. In an article published in 2001, Judy Peacock, Information Literacy Coordinator at the Queensland University of Technology Library in Australia, notes that "the shift of emphasis from training to education demands that the librarian attains a high level of educational credibility by demonstrating sound pedagogical knowledge and reflective practice, and by communicating effectively with faculty colleagues." ${ }^{12}$ She goes on to explain that, because librarians receive minimal training in these areas in graduate school, libraries themselves must address these issues. Peacock details her library's efforts in creating an in-house training program 
in information literacy instruction. The Professional Information Literacy Development Model (PILD) consists of four steps: Knowledge development (pedagogical foundations of teaching and learning), skills training (presentation skills and classroom management), observation of peers, and peer feedback. ${ }^{13}$

Long before the development and adoption of the proficiencies, literature existed urging for the creation of such a document. In a paper published in the 2001 LOEX Conference Proceedings, Lori Ricigliano outlined the importance of developing competencies in providing a framework of clear and realistic standards for good teaching. She defines competency as an interplay of knowledge, skills and attitudes and discusses how competencies can be used to inspire professionals, develop job descriptions, inform policies on professional behavior, create evaluation instruments, plan continuing education in-service programs, educate user communities about the standards of teaching librarians, and foster the expansion of courses on instruction in library schools. ${ }^{14}$ Similarly, in an article published in 2002, Carroll Botts and Mark Emmons describe the work of the University of New Mexico General Library to establish a list of teaching competencies to train and evaluate instruction librarians when they found themselves hiring recent library school graduates who did not have teaching experience. After collaboratively creating this list, instruction coordinators made it available to all instruction librarians and asked them to select a skill they needed to work on. Throughout the year, individuals would be evaluated by their peers and use feedback to write self-assessments. ${ }^{15}$

Due to the recent nature of the adoption of the proficiencies, the authors were able to find only one study where they were used as a tool for investigation and assessment. Beyond identifying how many institutions offered a course in instruction, Sproles, Johnson, and Farison looked at 34 syllabi of MLIS courses on instruction and analyzed the course outcomes against the 12 areas of proficiency. Not surprisingly, none of the courses covered all twelve areas, but those most heavily covered were instructional design and teaching skills. The authors were surprised to discover that communication skill was one of the less mentioned areas of proficiency; 14 of the courses studied made no mention of communication skills in their outcomes. ${ }^{16}$

Finally, it should be noted that, for a current, concise, and comprehensive overview of many aspects of the literature related to the topic of librarian teacher identity and development, readers should consult Scott Walter's 2008 article, "Librarians as Teachers: A Qualitative Inquiry into Professional Identity."17

\section{Research Questions}

The approval of the new set of proficiencies for instruction librarians in 2007 presented an opportunity to revisit the work of Shonrock and Mulder. In the years between the publication of the original set of proficiencies and the new set, instruction has become a ubiquitous piece of the reference librarian's portfolio. Was the new, more concise set of proficiencies more focused than the old? In the 14 years since Shonrock and Mulder's study, were librarians now more likely to have acquired the skills needed to be successful instructors through their library school coursework?

The authors were interested both in assessing the value that instruction librarians place on the current set of proficiencies and in looking at how things have changed since Shonrock and Mulder's 1993 study in terms of where librarians acquire and think they should acquire instructional proficiencies.

To compare the possible changes in acquisition of teaching proficiencies by instruction librarians over the years between the two studies, the base research questions replicated those of Shonrock and Mulder:

- How important are the individual proficiencies to instruction librarians? 
- Where are instruction librarians acquiring the proficiencies?

- Where do instruction librarians think they should be acquiring the proficiencies?

The focus of the authors' research was to determine how librarians felt about their education and preparation for the responsibilities of teaching. The questions posed were these:

- Are the current Proficiencies for Instruction Librarians and Coordinators, approved in 2007, perceived by Instruction Librarians to be important?

- Where are librarians acquiring proficiencies?

- Where do librarians feel they should be acquiring proficiencies?

- Do librarians seem to be acquiring proficiencies in library school more often than they were in 1993 ?

\section{Design of Survey 1}

Like Shonrock and Mulder's study, this study took place in two phases. In the first phase, survey respondents were asked to rate the importance of each individual proficiency. In the 2007 document, there are 68 proficiencies in total, 41 of them associated with instruction librarians and the other 27 associated with coordinators of instruction programs. The authors used only the 41 proficiencies specifically for instruction librarians (see table 2).

Shonrock and Mulder sent their first survey to 400 randomly selected members of BIS. Since the instruction section of ACRL now has a popular communication tool, the ILI-L listserv, participants for the current survey were intentionally solicited via the ILI-L listserv. As did Shonrock and Mulder, the authors asked respondents, "In your experience, how important is each of the following proficiencies for the effective performance of an instruction librarian?" The choices were: of no importance, of little importance, important, very important, essential, and don't know. ${ }^{18}$

\section{Results of Survey 1}

Of the 209 responses to the current survey, $175(83.7 \%)$ were usable. Similarly, Shonrock and Mulder received 144 usable responses to their first survey. The data were analyzed using Microsoft Excel. For the analysis, the scale was converted to the following numerical equivalents: $1=$ of no importance, 2 = of little importance, 3 = important, 4 = very important, 5 = essential. Don't know and no response were treated as missing values. Of the 41 proficiencies, $24(58.5 \%)$ had a mean greater than 4.0 . The median score of the 41 individual proficiencies was 4.2: Twenty proficiencies had a mean greater than 4.02 , and 21 had a mean of 4.02 or lower (see table 3 ).

Of the 12 categories, those containing proficiencies with the highest means were Planning Skills, Information Literacy Integration Skills, and Instructional Design Skills. Seven of the eleven proficiencies from these three combined categories fell into the more highly ranked half of proficiencies. The proficiencies with the highest means were:

1. 5.2 Collaborates with classroom faculty to integrate appropriate information literacy competencies, concepts, and skills into library instruction sessions, assignments, and course content (4.39).

2. 6.4 Assists learners to assess their information needs, differentiate among sources of information, and help them to develop skills to effectively identify, locate, and evaluate sources (4.39).

3. 6.5 Scales presentation content to the amount of time and space available (4.35).

4. 9.4 Seeks to clarify confusing terminology, avoids excessive jargon, and uses vocabulary appropriate for level of students (4.34).

5. 8.1 Plans presentation content and delivery in advance and manages preparation time for instruction (4.33).

Of the 12 categories, those containing proficiencies with the lowest means were 


\section{TABLE 2 \\ Proficiencies used in Phase 1 and Phase 2}

1. Administrative Skills

- Communicates own instruction activities and goals with the instruction coordinator on a regular basis to ensure alignment with desired learning outcomes and goals and objectives of the overall instruction program.

- Works well in a team environment and provides team with knowledge, skill, and time to improve instructional services.

- Maintains and regularly reports accurate statistics and other records reflecting own instruction activities.

2. Assessment and Evaluation Skills

- Designs effective assessments of student learning and uses the data collected to guide one's personal teaching and ongoing professional development.

3. Communication Skills

- Maintains awareness of communication needs of different learning styles, and adjusts own communication style and methods accordingly.

- Leads or facilitates discussion of controversial or unexpected issues in a skillful, non-judgmental manner that helps students to learn.

- Uses common communication technologies to provide assistance to students in and outside the classroom.

- Requests feedback from peers on instruction-related communication skills and uses it for self improvement.

4. Curriculum Knowledge

- Analyzes the curriculum in assigned subject area(s) to identify courses and programs appropriate for instruction.

- Keeps aware of student assignments and the role of the library in completing these assignments.

5. Information Literacy Integration Skills

- Describes the role of information literacy in academia and the patrons, programs, and departments they serve.

- Collaborates with classroom faculty to integrate appropriate information literacy competencies, concepts and skills into library instruction sessions, assignments and course content.

- Communicates with classroom faculty and administrators to collaboratively plan and implement the incremental integration of information literacy competencies and concepts within a subject discipline curriculum.

6. Instructional Design Skills

- Collaborates with classroom faculty by defining expectations and desired learning outcomes in order to determine appropriate information literacy proficiencies and resources to be introduced in library instruction.

- Sequences information in a lesson plan to guide the instruction session, course, workshop, or other instructional material.

- Creates learner-centered course content and incorporates activities directly tied to learning outcomes.

- Assists learners to assess their information needs, differentiate among sources of information and help them to develop skills to effectively identify, locate, and evaluate sources.

- Scales presentation content to the amount of time and space available.

- Designs instruction to best meet the common learning characteristics of learners, including prior knowledge and experience, motivation to learn, cognitive abilities, and circumstances under which they will be learning.

- Integrates appropriate technology into instruction to support experiential and collaborative learning as well as to improve student receptiveness, comprehension, and retention of information.

\section{Leadership Skills}

- Demonstrates initiative by actively seeking out instruction opportunities or instruction committee work within the library, on campus, in regional or national organizations.

- Encourages librarians and classroom faculty to participate in discussions, ask questions, and to share ideas regarding instruction.

8. Planning Skills

- Plans presentation content and delivery in advance, and manages preparation time for instruction. 
9. Presentation Skills

- Makes the best possible use of voice, eye contact, and gestures to keep class lively and students engaged.

- Presents instructional content in diverse ways (written, oral, visual, online, or using presentation software) and selects appropriate delivery methods according to class needs.

- Uses classroom instructional technologies and makes smooth transitions between technological tools.

- Seeks to clarify confusing terminology, avoids excessive jargon, and uses vocabulary appropriate for level of students.

- Practices or refines instruction content as necessary in order to achieve familiarity and confidence with planned presentation.

10. Promotion Skills

- Promotes library instruction opportunities and services to new faculty, underserved departments and programs, and elsewhere on campus, as relevant to one's instruction responsibilities and subject areas served.

- Establishes and maintains a working relationship with assigned academic departments and programs in order to incorporate library instruction into the curriculum and other educational initiatives.

- Represents the library and the instruction program in an effective and positive manner at local, regional, and national meetings and conferences.

11. Subject Expertise

- Keeps current with basic precepts, theories, methodologies, and topics in assigned and related subject areas and incorporates those ideas, as relevant, when planning instruction.

- Identifies core primary and secondary sources within the subject area and promotes the use of those resources through instruction.

- Uses the vocabulary for the subject and related disciplines in the classroom and when working with departmental faculty and students.

12. Teaching Skills

- Creates a learner-centered teaching environment by utilizing active, collaborative, and other appropriate learning activities.

- Modifies teaching methods and delivery to address different learning styles, language abilities, developmental skills, age groups, and the diverse needs of student learners.

- Participates in constructive student-teacher exchanges by encouraging students to ask and answer questions by allowing adequate time, rephrasing questions, and asking probing or engaging questions.

- Modifies teaching methods to match the class style and setting.

- Encourages teaching faculty during the class to participate in discussions, to link library instruction content to course content, and to answer student questions.

- Reflects on practice in order to improve teaching skills and acquires new knowledge of teaching methods and learning theories.

- Shares teaching skills and knowledge with other instructional staff.

SOURCE: Association of College and Research Libraries, "Association of College and Research Libraries Standards for Proficiencies for Instruction Librarians and Coordinators". Chicago, 2007. American Library Association. http://www.ala.org/ala/mgrps/divs/acrl/standards/profstandards.pdf.

Promotion Skills, Subject Expertise, Administrative Skills, and Communication Skills. Categories that did not contain any proficiencies with a mean greater than 4.02 were Subject Expertise, Leadership Skills, and Assessment Skills. The individual proficiencies with the lowest means were:

1. 10.3 Represents the library and the instruction program in an effective and positive manner at local, regional, and national meetings and conferences (3.31).
2. 11.3 Uses the vocabulary for the subject and related disciplines in the classroom and when working with departmental faculty and students (3.63).

3. 1.3 Maintains and regularly reports accurate statistics and other records reflecting own instruction activities (3.68).

4. $\quad 11.2$ Identifies core primary and secondary sources within the subject area and promotes the 
use of those resources through instruction (3.70).

5. 3.4 Requests feedback from peers on instruction-related communication skills and uses it for selfimprovement (3.73).

Shonrock and Mulder found the lowest mean to be 2.19 with a total variance $2.43 .^{19}$ In the current study, the lowest mean was 3.31 with a total variance 1.08 .

Additionally, in Shonrock and Mulder's study, only 29.8 percent of the proficiencies had a mean greater than $4.0 .^{20}$ In the current study, 58.5 percent of the proficiencies had a mean greater than 4.0. These differences indicate an overall improvement in the focus of the proficiencies, as a greater percentage of proficiencies in this document are, on average, ranked as "very important." Additionally, the considerable decrease in variance of means indicates that the current proficiencies are, as a whole document, perceived to be important to instruction librarians.

Shonrock and Mulder found that, by category, communication was of "those receiving the highest total means." ${ }^{21} \mathrm{Ad}-$ ditionally, all six of the communication proficiencies in their study were included in the top 25 proficiencies. In the current study, the Communication Skills category ranked 8th out of 12 in importance. Individually, of the four Communication Skills proficiencies, only one had a mean above 4.02, leaving three of the four Communication Skills proficiencies in the bottom half of the ranked set.

The categories with the highest total means were Presentation Skills, Instructional Design Skills, and Information Literacy Integration Skills. Of the categories containing more than one proficiency, none had all of its proficiencies included in the top half of the ranked set.

\section{Design of Survey 2}

Due to the large number of proficiencies, Shonrock and Mulder chose to create their second survey using the 25 proficiencies with the highest means, the five proficiencies with the lowest means, and the four proficiencies with the highest standard deviations. In total, they used 34 proficiencies in the second phase of their project. ${ }^{22}$ Shonrock and Mulder did not provide means for all of the proficiencies in their study. However, the five proficiencies ranked lowest had means of 2.89 or below, showing that at least abvg segment of the earlier list of proficiencies were ranked "of little importance," on average by surveyed instruction librarians. In the current study, all 41 proficiencies had a mean ranking of 3.31 or higher, meaning that, on average, instruction librarians found all of these proficiencies to be either important, very important, or essential to their jobs. As previously noted, 58.5 percent of the proficiencies had a mean of 4 or higher, meaning that over half, on average, were ranked as "very important." In the current study, the authors chose to use all 41 proficiencies in the second survey, since they were all ranked highly (see table 4).

Shonrock and Mulder sent their second survey to 400 randomly selected members of BIS. Again, respondents of the current survey were solicited via the ILI-L listserv. As in Shonrock and Mulder's second survey, respondents were asked, "For each proficiency, please indicate the most significant source from which you acquired it AND the most significant source from which you believe a librarian should acquire it." Respondents were able to choose from the following responses: library school, other formal education, continuing education, mentor/model, on-the-job, self-taught, and don't know/ don't have. ${ }^{23}$ Additionally, respondents were asked for their job title, whether or not they were involved in library instruction, the amount of time they had been involved in library instruction, and whether or not they had experience teaching prior to receiving their MLS. Out of 226 responses received, 159 (70\%) were usable. In comparison, Shonrock and Mulder received 181 usable responses to the second survey. The demographic data collected in the current study showed that 99 percent of respondents reported 
Proficiencies for Instruction Librarians 579

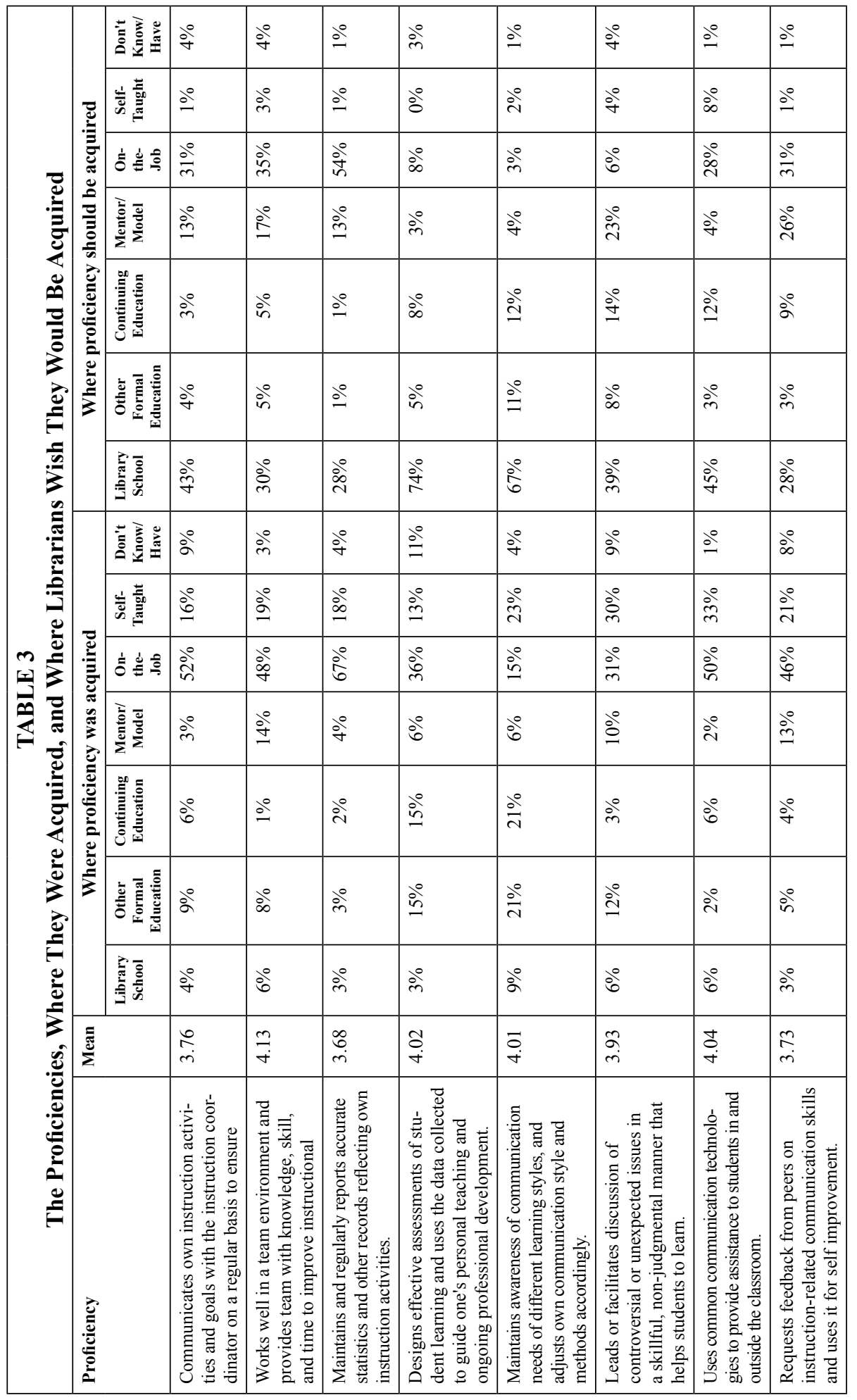




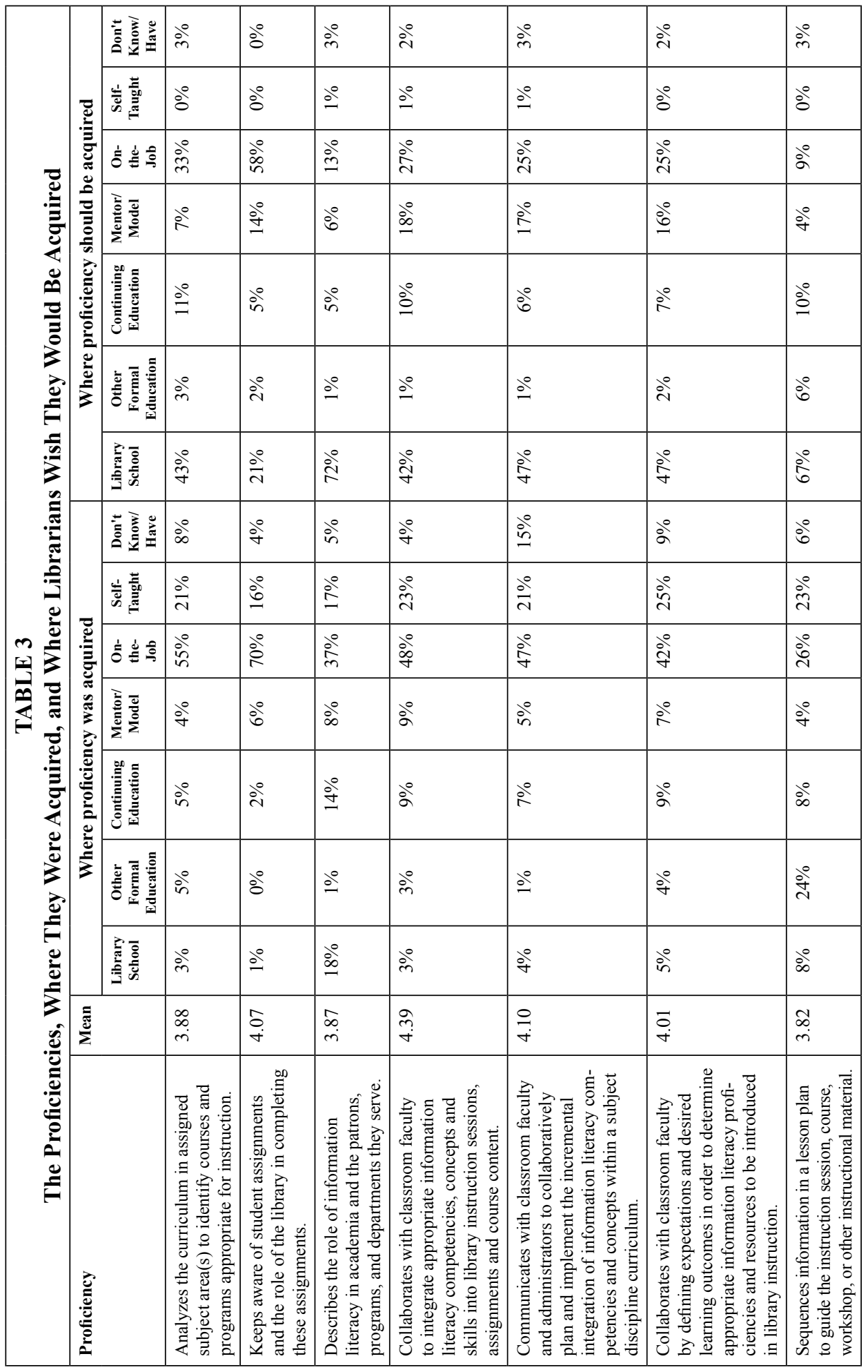


Proficiencies for Instruction Librarians 581

\begin{tabular}{|c|c|c|c|c|c|c|c|c|}
\hline & & 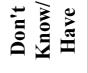 & $\grave{~}$ & ठे & $\therefore$ & के & $\therefore$ & $\grave{\hat{े}}$ \\
\hline & $\overline{0}$ & 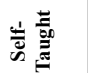 & ठे & $\therefore$ & $\stackrel{2}{2}$ & $\stackrel{\circ}{-}$ & $\stackrel{\circ}{2}$ & in \\
\hline \multirow{3}{*}{ 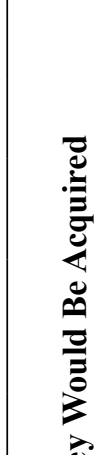 } & $\bar{\sigma}$ & 咅 & ఏे & $\stackrel{\circ}{\dot{\partial}}$ & 迥 & ذे & $\frac{\stackrel{\circ}{N}}{\partial}$ & $\stackrel{\circ}{\stackrel{0}{m}}$ \\
\hline & & 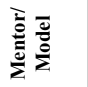 & in & 8̊ & ஸें & ذి & in & ले \\
\hline & & 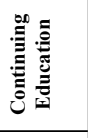 & $\stackrel{\infty}{\infty}$ & ळें & $\stackrel{\leftrightarrow}{\dot{\gamma}}$ & ळ & 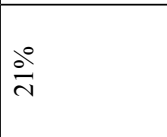 & in \\
\hline $\begin{array}{c}3 \\
\vec{E} \\
\vec{E}\end{array}$ & & 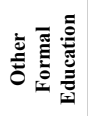 & $@$ & 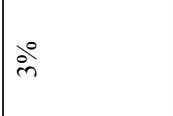 & خे & $\stackrel{2}{2}$ & $\stackrel{\circ}{2}$ & $\therefore$ \\
\hline 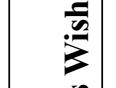 & & 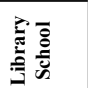 & خें & ஷे & 兽 & ठิ่ & 今ें & ठ응 \\
\hline$\stackrel{\bar{\pi}}{\bar{\pi}}$ & & 言言善 & $\stackrel{\leftrightarrow}{\dot{q}}$ & $\stackrel{\circ}{\circ}$ & ठ̊ & $\stackrel{\circ}{\circ}$ & in & $\stackrel{\leftrightarrow}{+}$ \\
\hline $\begin{array}{l}\frac{0}{3} \\
0 \\
0\end{array}$ & & 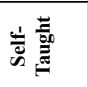 & $\partial^{\circ}$ & $\frac{\partial}{\lambda}$ & $\frac{\circ}{m}$ & ठ্ं & $\stackrel{\circ}{\stackrel{\circ}{~}}$ & dें \\
\hline$m \frac{\bar{\Xi}}{2}$ & 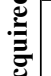 & 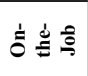 & 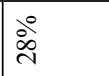 & ठ্ল & 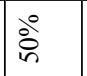 & ठें & $\begin{array}{l}8 \\
\frac{8}{4} \\
\frac{1}{4}\end{array}$ & $\stackrel{\text { ఫे }}{\circ}$ \\
\hline 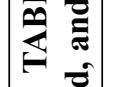 & $\begin{array}{l}0 \\
0 \\
\tilde{a} \\
2 \\
0\end{array}$ & 言 & $\stackrel{\infty}{\infty}$ & in & $\stackrel{\circ}{\dot{\gamma}}$ & in & ले & $\stackrel{\circ}{\stackrel{0}{ }}$ \\
\hline 意 & 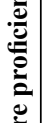 & 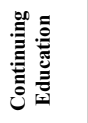 & @i & $\stackrel{\circ}{\dot{q}}$ & ํํำ & $\stackrel{\circ}{\doteq}$ & $\Omega^{\circ}$ & ले \\
\hline है & & 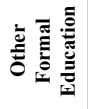 & $\stackrel{\circ}{\circ}$ & $\stackrel{\circ}{\circ}$ & 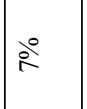 & 守 & in & $\stackrel{\circ}{\circ}$ \\
\hline 焉 & & 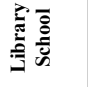 & bे & 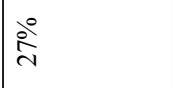 & in & ذి & $\therefore$ & ڤें \\
\hline $\begin{array}{c}3 \\
\dot{g}\end{array}$ & 离 & & $\stackrel{m}{\rightleftarrows}$ & के & $\stackrel{n}{m}$ & $\stackrel{I}{ғ}$ & \& & $\begin{array}{l}\stackrel{0}{0} \\
\dot{n}\end{array}$ \\
\hline 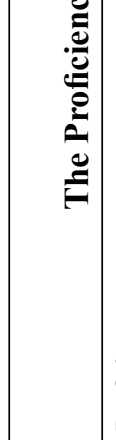 & 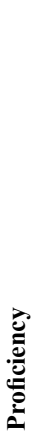 & & 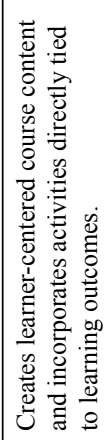 & 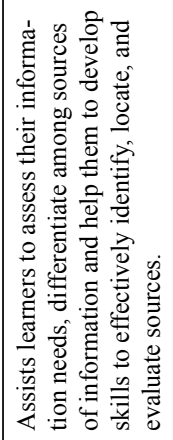 & 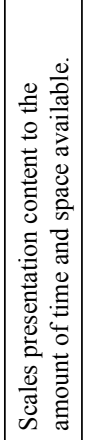 & 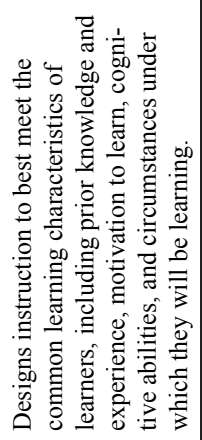 & 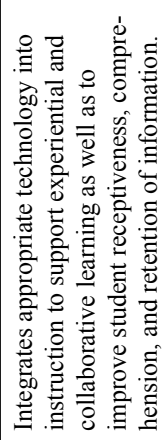 & 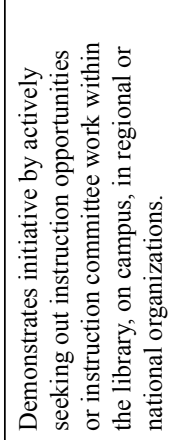 \\
\hline
\end{tabular}




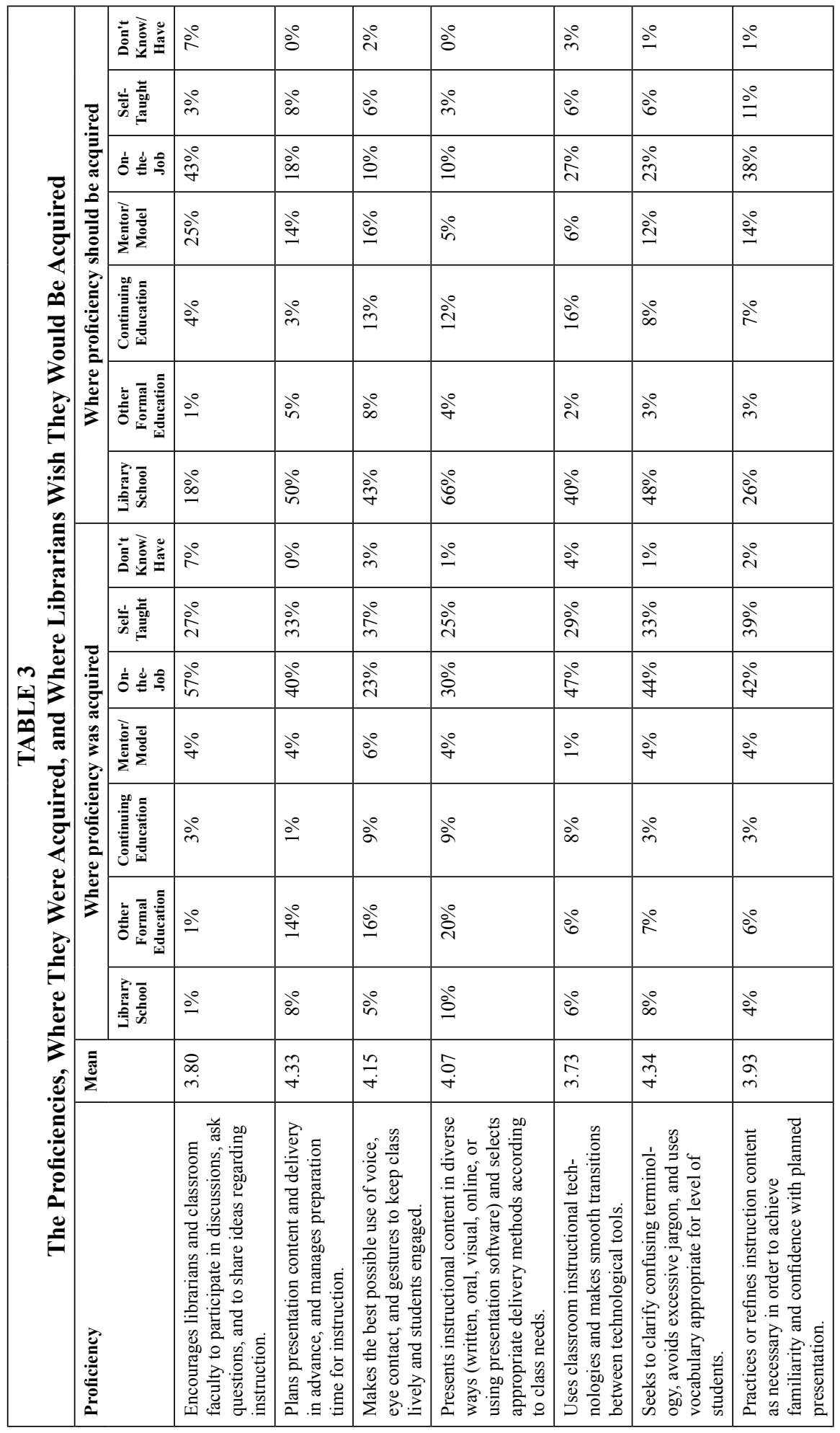


Proficiencies for Instruction Librarians 583

\begin{tabular}{|c|c|c|c|c|c|c|c|c|}
\hline \multirow{7}{*}{\multicolumn{2}{|c|}{ 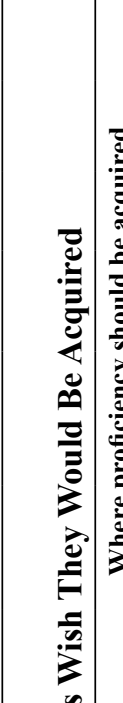 }} & 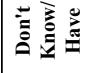 & $\cong$ & ले & $\stackrel{+}{+}$ & $\therefore$ & $\stackrel{+}{+}$ & iे \\
\hline & & 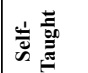 & ले & $\therefore$ & aे & @̊ & ले & iे \\
\hline & & 妾 & 字 & $\begin{array}{l}\stackrel{\circ}{8} \\
\text { fे }\end{array}$ & $\begin{array}{l}0 \\
\dot{\sim} \\
\text { iे }\end{array}$ & ळें & 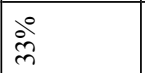 & 宇 \\
\hline & & 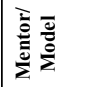 & ळें & 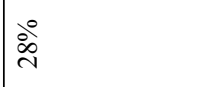 & 高 & $\stackrel{\circ}{\varrho}$ & $\stackrel{\circ}{\infty}$ & 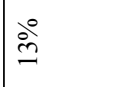 \\
\hline & & 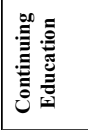 & bे & in & iे & ठ্ें & aे & aे \\
\hline & & 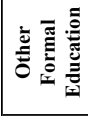 & $\stackrel{\circ}{-}$ & $\therefore$ & ठे & $\therefore$ & ले & $\stackrel{\circ}{=}$ \\
\hline & & 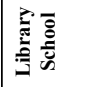 & $\stackrel{\circ}{\stackrel{0}{0}}$ & iั & 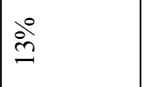 & ฝें & @े & 过 \\
\hline . & & 言言善 & अें & $\dot{b}^{\circ}$ & ฏे & $\stackrel{\leftrightarrow}{+}$ & ¿ें & $\stackrel{\leftrightarrow}{\dot{q}}$ \\
\hline 竒 & & 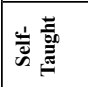 & ذें & तें & 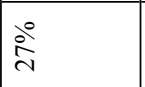 & iे & $\frac{\stackrel{0}{\sim}}{\grave{\lambda}}$ & ஸें \\
\hline$m \frac{0}{2}$ & 竒 & 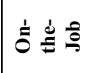 & 道 & ठें & $\begin{array}{l}0 \\
\infty \\
\text { mे }\end{array}$ & 商 & $\begin{array}{l}\stackrel{0}{8} \\
\frac{8}{y}\end{array}$ & ڤें \\
\hline 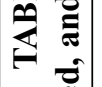 & $\begin{array}{l}\ddot{n} \\
\tilde{z} \\
0\end{array}$ & 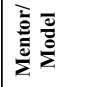 & $\stackrel{\circ}{=}$ & ลे & $\stackrel{\circ}{\circ}$ & in & $\stackrel{\circ}{\dot{\gamma}}$ & ले \\
\hline 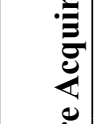 & 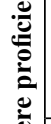 & 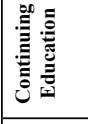 & $\therefore$ & $\therefore$ & ते & 응 & ले & $\stackrel{े}{ }$ \\
\hline $\begin{array}{l}\vec{e} \\
\vec{e} \\
\end{array}$ & ${ }^{\circ}$ & 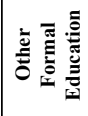 & $\mathrm{g}^{\circ}$ & $\therefore$ & $\mathrm{a}^{\circ}$ & ஸे & ले & $\stackrel{\infty}{\infty}$ \\
\hline 竞 & & 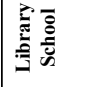 & ले & $\stackrel{\circ}{2}$ & ஸे & $\stackrel{\infty}{\infty}$ & $\stackrel{\circ}{0}$ & in \\
\hline 3 & 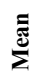 & & 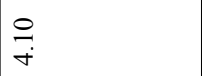 & \begin{tabular}{l}
$\stackrel{\text { \} }{+}} \\
{ }$ & $\vec{m}$ & $\stackrel{\vec{r}}{\dot{m}}$ & $\stackrel{R}{i}$ & $\begin{array}{l}\hat{\sigma} \\
\dot{m}\end{array}$ \\
\hline 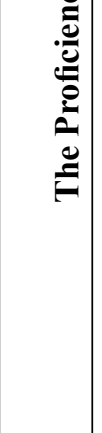 & 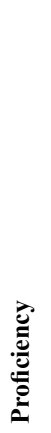 & & 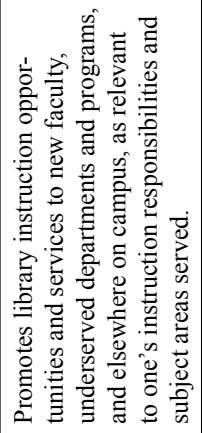 & 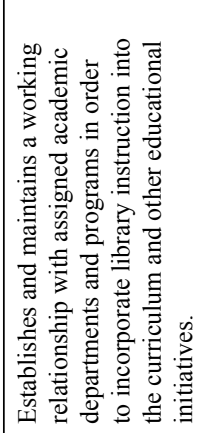 & 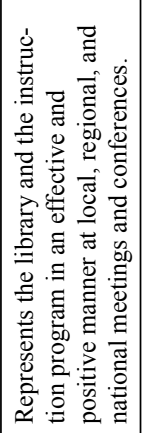 & 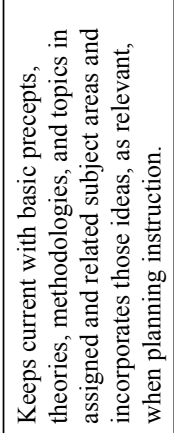 & 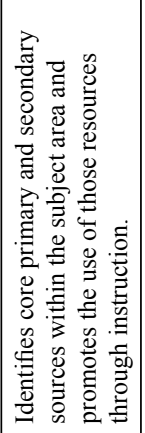 & 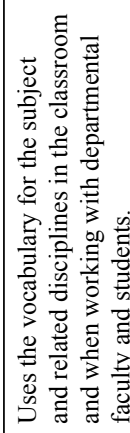 \\
\hline
\end{tabular}
\end{tabular}




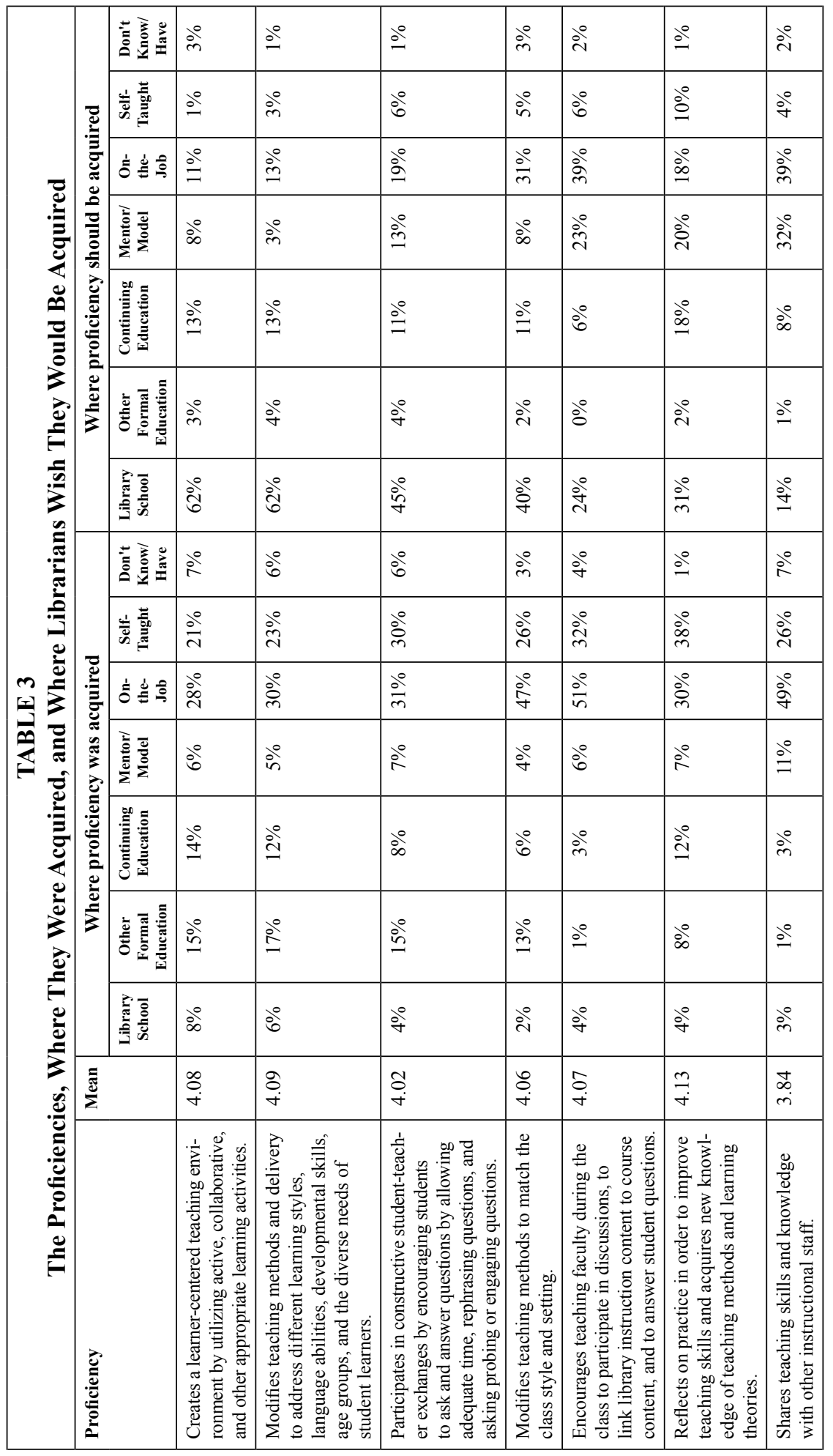




\begin{tabular}{|l|l|l|}
\hline \multicolumn{3}{|c|}{$\begin{array}{c}\text { TABLE 4 } \\
\text { Importance by Category } \\
\text { (Averages of Means) }\end{array}$} \\
\hline 1. & Planning Skills & 4.33 \\
\hline 2. & Instructional Design Skills & 4.12 \\
\hline 3. & Information Literacy Integration Skills & 4.11 \\
\hline 4. & Presentation Skills & 4.07 \\
\hline 5. & Teaching Skills & 4.02 \\
\hline 6. & Assessment Skills & 4.02 \\
\hline 7. & Curriculum Skills & 4.05 \\
\hline 8. & Communication Skills & 3.92 \\
\hline 9. & Administrative Skills & 3.83 \\
\hline 10. & Leadership Skills & 3.74 \\
\hline 11. & Promotion & 3.56 \\
\hline 12. & Subject expertise & 3.58 \\
\hline & & \\
\hline
\end{tabular}

to be involved in library instruction and 84 percent had been involved in library instruction for more than two years. Forty percent of respondents had teaching experience prior to obtaining their MLS. The data were analyzed using Microsoft Excel.

\section{Results: Where Did Librarians Learn These Proficiencies?}

Librarians reported to primarily learn 37 of the 41 proficiencies on the job. The remaining four proficiencies were primarily learned via self-teaching. These primarily self-taught proficiencies are:

- 3.1 Maintains awareness of communication needs of different learning styles and adjusts own communication style and methods accordingly.

- $\quad 9.1$ Makes the best possible use of voice, eye contact, and gestures to keep class lively and students engaged.

- $\quad$ 11.1 Keeps current with basic precepts, theories, methodologies, and topics in assigned and related subject areas and incorporates those ideas, as relevant, when planning instruction.

- 12.6 Reflects on practice to improve teaching skills and acquires new knowledge of teaching methods and learning theories.
None of the proficiencies were identified as having been learned primarily in library school. In the previous study, Shonrock and Mulder found two proficiencies to have been acquired primarily in library school, "[1] understanding the structure of information within various disciplines and the categories of tools necessary to use the information and [2] the ability to develop a search strategy." ${ }^{24}$ Neither of these skills is related specifically to instruction, however; they are skills that students expect to acquire in library school, regardless of the focus of study.

\section{Results: Where Do Librarians Feel They Should Learn These Proficiencies?}

Respondents listed library school or on the job as the most preferred method of acquiring 39 of the 41 proficiencies. For eleven proficiencies, more than 50 percent of respondents felt that proficiency should be acquired in library school (see table 5). In terms of the primarily preferred method of proficiency acquisition, respondents indicated library school for 27 proficiencies, on the job for 12 proficiencies, continuing education for one proficiency, and mentor/ model for one proficiency. As a whole, respondents felt that library school should be the primary place for librarians to acquire two-thirds of the proficiencies, yet all of them were primarily acquired on the job or self-taught.

For all 41 proficiencies, more respondents thought they should have acquired the proficiency in library school than did acquire it in library school. For 28 of the 41 proficiencies, the difference between the percentage who acquired the skill in library school and the percentage who thought it should be acquired in library school was greater than 25 percent. For nine of the 41 proficiencies, the difference was greater than 50 percent (see table 6). Four of the five proficiencies for which the difference was greatest deal with designing instruction (lesson plans, learner-center content, learning 
outcomes) to best meet the needs of students (by identifying learning styles and prior knowledge). For the one Assessment Skills proficiency, the difference in respondents who acquired it in library school and the respondents who thought they should have acquired it in library school was 71.1 percent.

Respondents indicated continuing education as the primarily preferred method of acquiring only one proficiency: "Keeps current with basic precepts, theories, methodologies, and topics in assigned and related subject areas and incorporate those ideas, as relevant, when planning instruction (11.1)." However, continuing education was the second most preferred method of proficiency acquisition for another eight proficiencies, most dealing with distinct classroom strategies and techniques.
Likewise, respondents indicated mentor/model as the primarily preferred method for acquiring only one proficiency: "Represents the library and the instruction program in an effective and positive manner at local, regional, and national meetings and conferences (10.3)." Mentor/model was the second most preferred method for proficiency acquisition for another eight proficiencies, all dealing with abstract ideas and theories.

Instruction librarians indicated that, in general, they do not prefer to acquire proficiencies on their own (self-taught) or via other formal education. Self-taught was the least preferred method for 22 proficiencies, and other formal education was the least preferred method for 20 proficiencies. However, there was a difference in librarians' least preferred methods

\begin{tabular}{|c|c|}
\hline \multicolumn{2}{|l|}{$\begin{array}{c}\text { TABLE } 5 \\
\text { Percentage of Respondents Who Feel the Proficiency Should be } \\
\text { Learned at Library School }\end{array}$} \\
\hline $\begin{array}{l}\text { Designs effective assessments of student learning and uses the data collected to guide one's } \\
\text { personal teaching and ongoing professional development. (Assessment Skills) }\end{array}$ & $74.2 \%$ \\
\hline $\begin{array}{l}\text { Assists learners to assess their information needs, differentiate among sources of informa- } \\
\text { tion and help them to develop skills to effectively identify, locate, and evaluate sources. } \\
\text { (Instructional Design Skills) }\end{array}$ & $72.8 \%$ \\
\hline $\begin{array}{l}\text { Describes the role of information literacy in academia and the patrons, programs, and de- } \\
\text { partments they serve. (Information Literacy Integration Skills) }\end{array}$ & $71.7 \%$ \\
\hline $\begin{array}{l}\text { Maintains awareness of communication needs of different learning styles, and adjusts own } \\
\text { communication style and methods accordingly. (Communication Skills) }\end{array}$ & $67.7 \%$ \\
\hline $\begin{array}{l}\text { Sequences information in a lesson plan to guide the instruction session, course, workshop, } \\
\text { or other instructional material. (Instructional Design Skills) }\end{array}$ & $67.7 \%$ \\
\hline $\begin{array}{l}\text { Presents instructional content in diverse ways (written, oral, visual, online, or using } \\
\text { presentation software) and selects appropriate delivery methods according to class needs. } \\
\text { (Presentation Skills) }\end{array}$ & $66.0 \%$ \\
\hline $\begin{array}{l}\text { Designs instruction to best meet the common learning characteristics of learners, including } \\
\text { prior knowledge and experience, motivation to learn, cognitive abilities, and circumstances } \\
\text { under which they will be learning. (Instructional Design Skills) }\end{array}$ & $63.3 \%$ \\
\hline $\begin{array}{l}\text { Creates learner-centered course content and incorporates activities directly tied to learning } \\
\text { outcomes. (Instructional Design Skills) }\end{array}$ & $62.7 \%$ \\
\hline $\begin{array}{l}\text { Modifies teaching methods and delivery to address different learning styles, language abilities, } \\
\text { developmental skills, age groups, and the diverse needs of student learners. (Teaching Skills) }\end{array}$ & $62.7 \%$ \\
\hline $\begin{array}{l}\text { Creates a learner-centered teaching environment by utilizing active, collaborative, and other } \\
\text { appropriate learning activities. (Teaching Skills) }\end{array}$ & $62.0 \%$ \\
\hline $\begin{array}{l}\text { Plans presentation content and delivery in advance, and manages preparation time for } \\
\text { instruction. (Planning Skills) }\end{array}$ & $50.6 \%$ \\
\hline
\end{tabular}


of acquiring proficiencies related to the amount of time they had been involved in instruction. Among librarians with more than ten years of involvement in library instruction, self-teaching was the least preferred method of acquiring 31 proficiencies and other formal education was the least preferred method for 17 proficiencies. Among librarians with fewer than two years' experience in instruction, these numbers were significantly lower. For librarians in this group, self-teaching was the least preferred method of acquiring proficiencies for 22 proficiencies, and other formal education was the least preferred acquisition method for 24 proficiencies (see figure 1).

\section{Conclusions}

The category that ranked the highest overall in importance was Planning Skills. However, this category only contains one proficiency, and it is important to the profession as a whole. Generally, planning skills, defined here as "managing preparation time," are important in all areas of librarianship and, certainly, most professional academic positions. The four categories that followed Planning Skills in order of importance are Instructional Design Skills, Information Literacy Integration Skills, Presentation Skills, and Teaching Skills. Each of these categories is specifically relevant to library instruction.

\begin{tabular}{|c|c|c|}
\hline \multicolumn{3}{|c|}{$\begin{array}{c}\text { TABLE } 6 \\
\text { Proficiencies with the Greatest Difference }(50 \%) \text { in } \\
\text { Whether the Proficiency was Acquired in Library School and } \\
\text { Whether it Should Have Been Acquired There }\end{array}$} \\
\hline & $\begin{array}{l}\text { \% who } \\
\text { acquired it in } \\
\text { library school }\end{array}$ & $\begin{array}{l}\% \text { who feel it } \\
\text { should be learned } \\
\text { in library school }\end{array}$ \\
\hline $\begin{array}{l}\text { Designs effective assessments of student learning and uses the data } \\
\text { collected to guide one's personal teaching and ongoing professional } \\
\text { development. (Assessment Skills) }\end{array}$ & $3.1 \%$ & $74.2 \%$ \\
\hline $\begin{array}{l}\text { Sequences information in a lesson plan to guide the instruction ses- } \\
\text { sion, course, workshop, or other instructional material. (Instruc- } \\
\text { tional Design Skills) }\end{array}$ & $8.2 \%$ & $67.7 \%$ \\
\hline $\begin{array}{l}\text { Maintains awareness of communication needs of different learning } \\
\text { styles, and adjusts own communication style and methods accord- } \\
\text { ingly. (Communication Skills) }\end{array}$ & $9.6 \%$ & $67.7 \%$ \\
\hline $\begin{array}{l}\text { Designs instruction to best meet the common learning characteris- } \\
\text { tics of learners, including prior knowledge and experience, motiva- } \\
\text { tion to learn, cognitive abilities, and circumstances under which } \\
\text { they will be learning. (Instructional Design Skills) }\end{array}$ & $5.7 \%$ & $63.3 \%$ \\
\hline $\begin{array}{l}\text { Creates learner-centered course content and incorporates activities } \\
\text { directly tied to learning outcomes. (Instructional Design Skills) }\end{array}$ & $6.3 \%$ & $62.7 \%$ \\
\hline $\begin{array}{l}\text { Modifies teaching methods and delivery to address different learn- } \\
\text { ing styles, language abilities, developmental skills, age groups, and } \\
\text { the diverse needs of student learners. (Teaching Skills) }\end{array}$ & $6.3 \%$ & $62.7 \%$ \\
\hline $\begin{array}{l}\text { Presents instructional content in diverse ways (written, oral, visual, } \\
\text { online, or using presentation software) and selects appropriate deliv- } \\
\text { ery methods according to class needs. (Presentation Skills) }\end{array}$ & $10.1 \%$ & $66.0 \%$ \\
\hline $\begin{array}{l}\text { Creates a learner-centered teaching environment by utilizing active, col- } \\
\text { laborative, and other appropriate learning activities. (Teaching Skills) }\end{array}$ & $8.2 \%$ & $62.0 \%$ \\
\hline $\begin{array}{l}\text { Describes the role of information literacy in academia and the pa- } \\
\text { trons, programs, and departments they serve. (Information Literacy } \\
\text { Integration Skills) }\end{array}$ & $18.2 \%$ & $71.7 \%$ \\
\hline
\end{tabular}




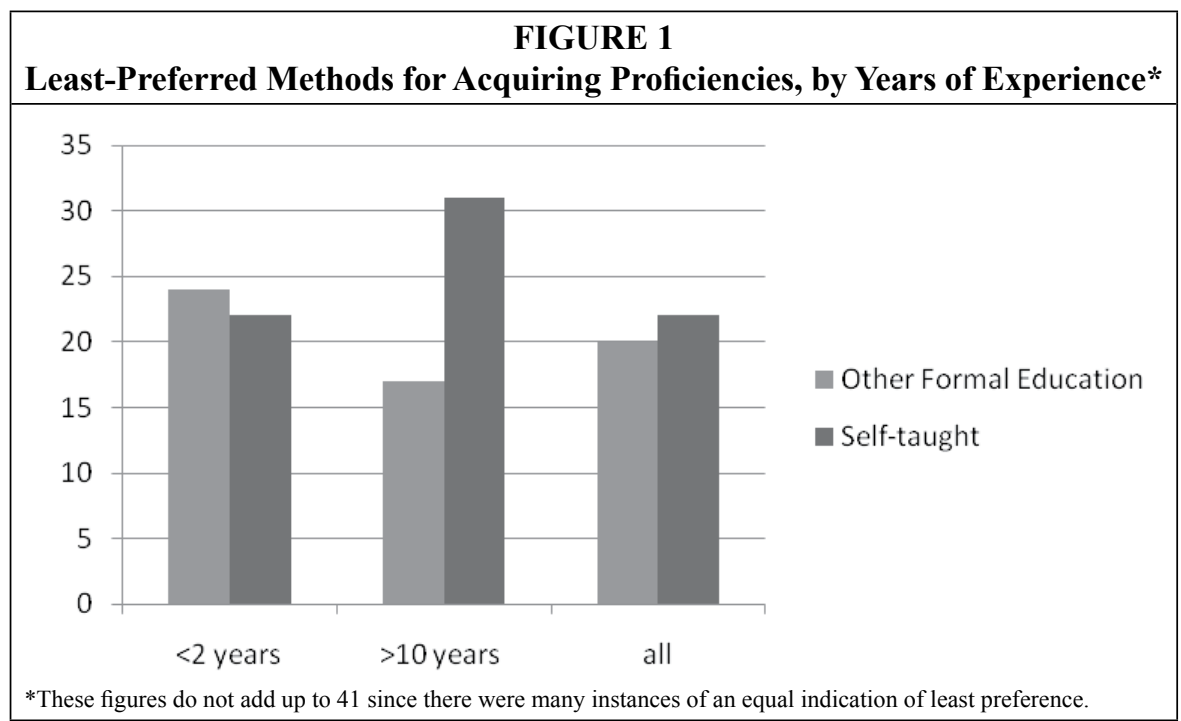

A comparison of importance of proficiencies by category shows a change in priority among instruction librarians over the years. Shonrock and Mulder found two of the three most important categories were categories related to librarians generally: "communication skills, instructional ability, and planning ability," with communication "clearly the most important category." ${ }^{25}$ The current results illustrate that four of the five most important categories are those with specific relevance to instruction (see table 4). Like increased importance of proficiencies overall, this indicates an improvement in the quality of proficiencies in terms of both relevance to instruction librarians and proper alignment with needed skills. Additionally, this shift points to the increase of instruction as a part of librarians' everyday workloads: if librarians are spending more time teaching, they are likely to be more concerned with skills related to teaching.

Although librarians showed a strong preference for acquiring most of the proficiencies in library school, many also showed preference for acquiring the proficiencies on the job. Unlike Shonrock and Mulder, who found that librarians preferred to acquire proficiencies in other formal education settings (in addition, of course, to library school), the current results show that librarians actually prefer other formal education as a method of acquiring proficiencies second least. Additionally, for librarians with fewer than two years of involvement in instruction, acquiring the proficiencies via other formal education was the least preferred method.

Instruction librarians have indicated that they find this current set of proficiencies to be important to their effective performance as instruction librarians. As long as librarians are reporting to acquire proficiencies primarily on the job, it is important that instruction programs provide appropriate training. Formalizing on-thejob experiences through mentoring, workshops, reading groups, and other types of training to address the proficiencies will benefit instruction librarians, instruction programs, and the recipients of instruction alike. There is little indication that the proficiencies are being adopted by instruction programs as a standard for measuring skills, library schools as a template for curricular change, or administrators as a guide for writing job descriptions. Based on the importance of the proficiencies, as indicated in this study, they should be given attention equivalent to that given to other sets of proficiencies important to the field of instruction. 
Certainly, there was a time when instruction was rare and most patron interaction took place at the reference desk. It did not make sense then to think of instruction as a type of position in a library and, therefore, an addition to library school curricula. ${ }^{26}$ However, half of the respondents to the present study have position titles containing either "instruction" or "information literacy" (if not out of interest, out of necessity). As long as libraries are expecting librarians to teach, instruction programs must be prepared to provide, or at least guide, the environment and support necessary for instruction librarians to thrive in the positions they have been hired to fill. The set of proficiencies in this document is the perfect tool to facilitate the guidance necessary for this important task.

\section{Limitations of Study}

Respondents were asked, "How long have you been involved in library instruction?" The authors assumed that respondents with fewer than two years of experience in library instruction were recent graduates of library school. However, the results quickly indicated that this might not have been the case. It would have been useful to know when respondents had graduated from library school. With this information, a change in curriculum might have been apparent.

Certain proficiencies might have a higher likelihood of being acquired early in a librarian's career. Likewise, some may take time to acquire. Librarians with more years of experience might be more likely to report that they have acquired skills on the job even if they had originally acquired those skills in library school and perfected them on the job. Where, in this study, all proficiencies were treated equally, it might be useful to rank proficiencies by their priority or even by their perceived ability to be acquired in library school. Continuing education opportunities for librarians provide a natural place to look for the incorporation and inclusion of proficiency acquisition.
As a comparative study, the authors were limited in that the new set of proficiencies is distinct from the set used by Shonrock and Mulder in 1993. Though the methodologies of the two studies were nearly identical, the studies were based on differing sets of proficiencies. This leads to an investigation that can compare trends in attitudes and values of instruction librarians over time, rather than explicit, quantitative changes over time.

\section{Recommendations}

Clearly, library school is not where librarians are acquiring the proficiencies that they later find very important to their work in instruction. Sproles, Johnson, and Farison show that library schools do offer classes in instruction, ${ }^{27}$ but they do not look further than the course syllabi. If there is a disconnect between library school curricula and professional proficiencies, it needs to be addressed. Recent graduates who have taken courses in instruction could provide valuable insight into whether or not their coursework has prepared them for their real work. Additionally, the disconnect might also reside between the academic expectations and professional expectations.

Presently, there are no studies looking at the use or application of the Standards for Proficiencies for Instruction Librarians and Coordinators in professional situations. Are libraries incorporating them into performance evaluations or using them to set departmental goals? Are instruction programs using the proficiencies to guide professional development programming? While this study shows that librarians find the proficiencies to be important to their work, administrators will also need to find value in the document so that it may gain professionwide momentum. It is likely that many administrators are not aware that the current set of proficiencies exists. While there is near-ubiquitous focus on the Information Literacy Competency Standards, it seems just as important to focus on the proficiencies of those individuals responsible for delivering those competencies. 
Ultimately, it is not necessary that instruction librarians acquire teaching skills in library school, but instead that they have access to effective methods for acquiring these skills as they need them. It will be interesting to watch how libraries use these proficiencies to map their instruction programs, plan for continuing education and other professional development opportunities, and collaborate with library schools to enrich the educational experiences of prospective instruction librarians.

\section{Notes}

1. A copy of these proficiencies is available online at $<\mathrm{http}: / /$ library.csus.edu/services/inst/ indiv/acrl_bis_profic.htm>. [Accessed 14 September 2009].

2. Diana D. Shonrock and Craig Mulder, "Instruction Librarians: Acquiring the Proficiencies Critical to Their Work," College \& Research Libraries 54 (1993): 137-49.

3. Association of College and Research Libraries, "Association of College and Research Libraries Standards for Proficiencies for Instruction Librarians and Coordinators" (Chicago: American Library Association, 2007). Available online at <www.ala.org/ala/mgrps/divs/acrl/ standards/profstandards.pdf >. [Accessed 14 September 2009].

4. Ibid.

5. Chris Avery and Kevin Ketchner, "Do Instructional Skills Impress Employers?" 57, no. 3 (1996): 249-53.

6. Lynn Westbrook, "Passing the Halfway Mark: LIS Curricula Incorporating User Education Courses," Journal of Education for Library and Information Science 40, no. 2 (1999): 92-98.

7. Ibid., 96.

8. Rebecca Albrecht and Sara Baron, "The Politics of Pedagogy: Expectations and Reality for Information Literacy in Librarianship," Journal of Library Administration 36, no. 1-2 (2002): 71-96.

9. Heidi Julien, "Education for Information Literacy Instruction: A Global Perspective," Journal of Education for Library and Information Science 46, no. 3 (2005): 210-16.

10. Claudene Sproles, Anna Marie Johnson, and Leslie Farison, “What the Teachers Are Teaching: How MLIS Programs Are Preparing Academic Librarians for Instructional Roles," Journal of Education for Library and Information Science 49, no. 3 (2008): 195-209.

11. Scott Walter, "Instructional Improvement: Building Capacity for the Professional Development of Librarians as Teachers," Reference \& User Services Quarterly 45, no. 3(2006): 213-18.

12. Judith Peacock, "Teaching Skills for Teaching Librarians: Postcards from the Edge of the Educational Paradigm at Queensland University of Technology," Australian Academic \& Research Libraries 32, no. 1 (2001): 26-42.

13. Ibid.

14. Lori Ricigliano, "Making the Grade: Teaching Competencies for Academic Librarians," in Managing Library Instruction Programs in Academic Libraries: Selected Papers Presented at the TwentyNinth National LOEX Library Instruction Conference," ed. Julia K. Nims and Eric Owen (Ann Arbor, Mich.: Pierian Press, 2003).

15. Carroll Botts and Mark Emmons, "Developing Teaching Competencies for Instructors in the Academic Library: A Case Study," Public Services Quarterly 1, no. 3 (2002): 65-81.

16. Sproles, Johnson, and, Farison, "What the Teachers Are Teaching."

17. Scott Walter, "Librarians as Teachers: A Qualitative Inquiry into Professional Identity," College \& Research Libraries 69, no. 1 (2008): 51-71.

18. Shonrock and Mulder, "Instruction Librarians," 140.

19. Ibid., 141.

20. Ibid., 140.

21. Ibid.

22. Ibid., 141.

23. Ibid.

24. Ibid., 144.

25. Ibid., 140.

26. Robert E. Brundin, "Education for Instructional Librarians: Development and Overview," Journal of Education for Library and Information Science 25 (Winter 1985): 177-89.

27. Sproles, Johnson, and, Farison, "What the Teachers Are Teaching." 


\title{
Choice Reviews Online
} www.cro2.org

Visit the Choice table, \#49, at the Charleston Conference Vendor Showcase to see a demonstration of the new features on

Choice Reviews Online.

\author{
In Charleston, SC \\ November 3, 2010.
}

For a free 60-day trial to Choice Reviews Online visit www.cro2.org.

For more information visit www.cro2.org. 